$\left.\int \begin{array}{c}\text { Jurnal Penelitian dan Evaluasi Pendidikan } \\ \text { Volume 20, No 1, Juni 2016 (98-110) }\end{array}\right)$

\title{
PENGEMBANGAN INSTRUMEN BAKAT KEGURUAN
}

\author{
1)W asidi, 2)Djemari Mardapi \\ 1)Universitas Bengkulu, 2)Universitas Negeri Yogyakarta \\ 1wasidirma@gmail.com, 2)djemarimardapi@gmail.com
}

\begin{abstract}
Abstrak
Tujuan penelitian ini adalah untuk mengembangkan instrumen bakat keguruan yang valid dan reliabel. Penelitian ini dilakukan dengan tiga tahap yaitu: pra-pengembangan, pengembangan konseptual, dan uji coba instrumen. Data dianalisis dengan item response theory partial credit model, analisis faktor konfirmatori, validitas konkuren, validitas konvergen, dan koefisien reliabilitas. Hasil penelitian menunjukkan bahwa instrumen bakat keguruan terdiri atas tiga dimensi yaitu kreativitas pedagogi, komitmen pedagogi, dan kecerdasan emosi. Ketiga dimensi instrumen bakat keguruan memenuhi syarat IRT PCM. Hasil confirmatory factor analysis menunjukkan bahwa instrumen bakat keguruan fit. Koefisien reliabilitas gabungan tinggi. Analisis multitrait multimethod menunjukkan bahwa korelasi antara skor kreativitas pedagogi dengan skor IQ rendah. Korelasi antara skor komitmen pedagogi dengan skor Edwards Personal Preference Schedule adalah cukup. Korelasi antara skor kecerdasan emosi dengan skor EPPS adalah cukup. Validitas konvergen dimensi komitmen pedagogi termasuk tinggi, dan validitas konvergen kecerdasan emosi termasuk tinggi. Dengan demikian instrumen bakat keguruan mempunyai validitas isi, validitas konstruk, dan validitas konvergen yang baik, sedangkan dimensi komitmen pedagogi dan kecerdasan emosi mempunyai validitas konkuren yang termasuk kategori cukup. Koefisien reliabilitas gabungan instrumen bakat keguruan memenuhi persyaratan minimal. Dengan demikian instrumen bakat keguruan dapat digunakan oleh LPTK sebagai tes bakat calon mahasiswa.
\end{abstract}

Kata kunci: bakat keguruan, validitas isi, validitas konstruk, validitas konkuren, validitas konvergen, koefisien reliabilitas gabungan

\section{DEVELOPING A TEACHER APTITUDE INSTRUMENT}

\author{
1)Wasidi, 2Djemari Mardapi \\ 1)Universitas Bengkulu, ${ }^{2)}$ Universitas Negeri Yogyakarta \\ 1)wasidirma@gmail.com, 2)djemarimardapi@gmail.com
}

\begin{abstract}
The purpose of this study is to develop an instrument of teacher aptitude which is valid and reliable. This research was carried out in three phases: pre-development, conceptual development, and instrument try out. The data were analyzed using the item response theory partial credit model, confirmatory factor analysis, concurrent validity, convergent validity, and reliability coefficient. The result of this research is a teacher aptitude instrument that consists of three dimensions: pedagogical creativity, pedagogical commitment, and emotional intelligence. The three dimensions of the instrument have IRT PCM qualification. The result of CFA shows that the teacher aptitude instrument is fit. The coefficient of the reliability is high. The correlation between pedagogical creativity score and intelligence quotient score is low. The correlation between pedagogical commitment and Edwards Personal Preference Schedule score is sufficient. The correlation between emotional intelligence score and EPPS score is sufficient. The convergent validity of pedagogical commitment is high, while the convergent validity of emotional intelligence is high. Therefore the teacher aptitude instrument has a good content validity, construct validity, and convergent validity, while dimension of pedagogical commitment and emotional intelligence has sufficient concurrent validity. The coefficient of composite reliability of the instrument meets the minimum requirements. Therefore the teacher aptitude instrument could be used by LPTK as an aptitude test for student candidates.
\end{abstract}

Keywords: teacher aptitude, content validity, construct validity, convergent validity, coefficient of composite reliability 



\section{Pendahuluan}

Undang-Undang Nomor 20 Tahun 2003, Undang-Undang tentang Guru dan dosen No. 14 Tahun 2005 pasal 7, dan Peraturan Pemerintah No.19 Tahun 2005 pasal 28 mensyaratkan guru ideal akademik dan non-akademik. Keberadaan guru dalam proses pendidikan sangat penting yang tidak dapat digantikan oleh apapun (Block, 2008; Sudarnoto, 2009). Banyak penelitian yang mendukung pentingnya guru dalam proses pendidikan dan pembelajaran, namun ada kesenjangan antara harapan dan kenyataan (Alkharusi, Kazem, \& Musawai 2011; Dicky, 2011; Mardiana, 2006; Rowe, 2003; Sugiharto, 2003). Pengaruh karakter (aspek non-kognitif) guru sangat besar terhadap perkembangan peserta didik serta keberhasilan pendidikan (Açikgöz, 2005; Dorman, 2008; Garcia, Kupczynski, \& Holland, 2011; Ishak, Piet, \& Ramli, 2010; Jacobs \& Mitchell 2008; Justice \& Espinoza, 2007; Kokkinos, Charalambous, \& Davazoglou 2010). Namun, dalam seleksi calon guru belum digunakan instrumen non-kognitif sebagai bahan pertimbangan kelulusan, karena belum tersedianya instrumen karakter/ non-kognitif. Untuk mengisi kekosongan tersebut maka dikembangkan instrumen bakat keguruan yang mencakup bakat nonkognitif yang memenuhi syarat validitas dan reliabilitas. Masalah pokok dalam penelitian ini adalah bagaimana konstruk bakat keguruan, dan berapa koefisien reliabilitasnya.

Bakat pada awalnya mengacu pada pengertian kecerdasan (intelligence). Bakat adalah kondisi. Aptitude adalah kondisi atau cirikhas dianggap sebagai gejala kemampuan individu untuk memperoleh pelatihan, biasanya berupa pengetahuan, keterampilan atau tanggapan, seperti kemampuan untuk berbicara bahasa, untuk menghasilkan musik (Bingham, 1948), sedangkan Martinson (1974) menyebutkan bahwa anak-anak berbakat dan berbakat diidentifikasi sebagai individu yang berkualitas, mampu berkinerja tinggi. Salkind (2008) menyebutkan bahwa bakat adalah perbedaan individu yang berkaitan dengan pembelajaran berikutnya dalam jangka waktu yang sama. Perbedaan in- dividu dapat terjadi pada ranah cognitive dan non-cognitive. Aptitude mengacu pada kualitas karakteristik perilaku orang yang menunjukkan seberapa baik ia dapat belajar untuk memenuhi dan memecahkan masalah tertentu. Ada prasyarat individu untuk dapat menguasai keahlian tertentu, prasyarat itulah yang dimaksud dengan bakat.

Teori bakat telah berubah, Renzulli (1986, pp. 53-93) yang didukung oleh Sternberg \& Davidson (2005, pp.246-273) mengemukakan bahwa keberbakatan adalah multidimensi dan dapat diletakkan di setiap area kemampuan manusia. Bakat merupakan interaksi antara tiga kelompok dasar sifat manusia yaitu kemampuan umum di atas rata-rata, tingkat komitmen tugas dan tingkat. Ketiga dimensi tersebut dikenal dengan teori the three ring concepts. Renzulli dalam Baum, Reis, \& Maxfield (1998) mengatakan bahwa kemampuan umum adalah kemampuan verbal, numerik, spasial, ingatan, yang biasanya diukur dengan kecerdasan umum. Namun Gardner (2006, pp. 8-24) mengatakan bahwa kecerdasan ada 8 jenis, dua di antaranya adalah kecerdasan antarpersonal dan interpersonal. Kecerdasan emosional meliputi interpersonal dan intrapersonal yang merujuk berbagai keterampilan yang terkait dengan emosi diri sendiri dan emosi orang lain, mempelajari perilaku dan tanggapan terhadap emosi orang lain, mampu untuk berbagi pengalaman positif yang bermakna kepada orang lain, dan kemampuan untuk berhubungan dengan mereka (Sigmar, Hynes, \& Cooper, 2010). Kecerdasan emosi diperlukan oleh guru dalam melaksanakan tugas mendidik, guru yang baik adalah seorang yang dapat sebagai pamong yang mempunyai kecerdasan emosi yang bagus, yang dapat mengendalikan dan mengelola emosinya dengan baik. (Anonim, 1977, p.16; Sudiyat, 1987, p.3). Kemampuan di atas ratarata (above average ability) dalam konsep bakat keguruan dapat digantikan dengan kecerdasan emosi, dengan demikian bakat keguruan terdiri atas kreativitas pedagogi, komitmen pedagogi, dan kecerdasan emosi. Bakat keguruan adalah potensi kemampuan individu dapat berkembang dengan pendidikan untuk 
melaksanakan proses pendidikan dan pembelajaran dengan baik.

Kreativitas dalam pendidikan terdiri atas aspek: orisinalitas, imajinasi, pemecahan masalah, adaptasi, jaringan dan komunikasi (Dawson Tan, \& McWilliam 2011). Mengajar kreatif adalah pembelajaran yang dilakukan dengan tertib, dan dengan improvisasi dan dalam cakupan kinerja yang luas (Sawyer, 2004). Merencanakan pembelajaran merupakan sebuah pekerjaan kreatif, ibaratnya dipandang sebagai menulis sebuah skenario pembelajaran (Beetlestones, 2011, p.172). Guru yang kreatif dapat dilihat dengan ciri-ciri rasa ingin tahu, berpikir orisinal, mandiri, berani mengambilan risiko, energik, mempunyai rasa humor, memecahkan suatu masalah yang kompleks, artistik, berpikiran terbuka, dan intuitif (Lilly \& Bramwell-Rejskind 2004). Guru yang kreatif akan meningkatkan motivasi siswa dan dirinya, selain itu dalam mengajar akan memanfaatkan kecerdasan personal dalam memilih kegiatan yang sesuai dengan minat dan kebutuhan siswa dan guru itu sendiri (Bramwell, Reilly, Lilly, Kronish, \& Chennabathni, 2011). Pengalaman kerja akan membatu guru menemukan kreativitas sendiri, dengan kreativitasnya tersebut guru dapat membantu kesulitan siswa sesuai dengan kendala yang terjadi di kelas (Dawson, Tan, \& McWilliam 2011).

Seorang guru harus paham kondisi pergaulan peserta didik. Dalam pergaulan antarpeserta didik kadang bahkan sering terjadi bullying. Guru di samping sebagai pendidik juga sebagai psikolog, sebagai psikolog dapat mengidentifikasi anak-anak yang agresif dan pasif yang dapat digunakan sebagai bahan menentukan langkah-langkah yang tepat untuk membantu anak-anak tersebut (Leff, Kupersmidt, \& Power, 1999). Pelaksanaan aturan sangsi tegas terhadap kekerasan atau intimidasi, adanya pujian bagi siswa yang berprestasi, peningkatan pengawasan selama istirahat akan tercipta kondisi iklim sekolah yang baik (Roth, Kanat-Maymon, \& Bibi, 2010). Selanjutnya, guru dapat menciptakan suasana yang menyenangkan akan membuat pembelajaran lebih efektif (Strean,
2011). Kedalaman pemahaman guru terhadap kemampuan setiap siswa pada gilirannya akan mempengaruhi kualitas penilaian siswa (Stiggins, 1992).

Pada umumnya guru di samping mempunyai pekerjaan yang berat sebagai pendidik, juga dengan sukarela akan memberikan waktu ekstra untuk membantu dalam menangani berbagai masalah siswanya (Twemlow, et al, 2006). Guru memberikan tambahan waktu, pikiran dan tenaga bagi siswa, sekolah, dan pelajaran (Choi, 2009). Guru mengembangkan pembelajaran di sekolah, mengajar merupakan tuntutan jiwa pendidik, mengajar sebagai karir, dan berinteraksi dengan siswa dengan attitude yang baik (Kwok-wai, 2006). Guru yang mempunyai komitmen akan berperilaku disiplin, bekerja keras-ulet, bertanggung jawab, bermotivasi kerja tinggi (Razak, Darmawan, \& Keeves, 2010). Guru berkualitas dapat dilihat pada kualitas pengajaran dan pembelajaran walaupun masih tradisional yang diperolehnya selama bertahun-tahun ( $\mathrm{Gu}$ \& Day, 2013). Komunikasi guru dan keluarga secara berkala akan meningkatkan penyelesaian tugas di luar sekolah, meningkatkan kualitas perilaku dan partisipasi peserta didik di kelas (Kraft \& Dougherty, 2013).

Kecerdasan emosi merujuk pada kemampuan seseorang untuk memahami arti emosi diri sendiri dan hubungan dengan orang lain, dan dapat mengatasi masalah berdasarkan problemnya (Mayer, Caruso, \& Salovey, 2000). Guru adalah orang empati yang dapat memahami perasaan siswa dan menanggapi perasaan mereka dengan tepat (Olson \& Wyett, 2000). Guru yang cerdas emosinya lebih sesuai sebagai sebagai pemimpin. Guru dapat mengelola secara efektif rasa marah atau frustrasi, dan dapat berperilaku adaptif sesuai dengan kondisi situasi yang berbeda. Jika menghadapi siswa yang bermasalah akan menanggapi siswanya dengan tepat (Iordanoglou, 2007). Ketika ada siswa mengganggu siswa lain, guru yang bijaksana segera menangani masalah tersebut dengan baik tanpa menimbulkan masalah baru (Twemlow, et al, 2006). Kepedulian guru yang baik terhadap siswa akan 
mempengaruhi perilaku siswa kepada guru tersebut (Teven, 2007). Kecerdasan emosi (Patton, 1977; Sundari, 2013) terdiri atas lima komponen yaitu mengenali emosi sendiri, mengelola emosi, empati, dan keterampilan sosial.

Instrumen bakat keguruan terdiri atas kreativitas pedagogi dengan indikator-indikator kecepatan berpikir, keluwesan berpikir, keaslian berpikir, dan elaborasi berpikir. Kecepatan berpikir adalah tingkat kemampuan memproduksi alternatif pemecahan pendidikan dalam batas waktu yang ditentukan. Keluwesan berpikir adalah kemampuan mencari alternatif pemecahan masalah pendidikan dalam waktu yang ditentukan. Keaslian berpikir adalah kemampuan memproduksi alternatif masalah yang baru atau bersifat sintesa dalam waktu yang ditentukan. Elaborasi berpikir adalah kemampuan mencari alternatif lain yang lebih luas pada pemecahan masalah yang sudah ada sebelumnya pada waktu yang ditentukan.

Komitmen pedagogi terdiri atas empat faktor yaitu motivasi terhadap tugas, disiplin terhadap tugas, tanggung jawab terhadap tugas, dan keuletan menjalankan tugas. Motivasi terhadap tugas adalah dorongan dari dalam dan luar untuk menyelesaian tugas yang diembannya. Disiplin terhadap pelaksanaan tugas adalah tingkat ketepatan waktu yang diperlukan untuk melaksanakan tugas yang diembannya. Tanggung jawab terhadap tugas adalah tingkat keberanian menanggung beban yang diembannya. Keuletan dalam menjalankan tugas adalah tingkat kegigihan pelaksanaan tugas yang diembannya.

Kecerdasan emosi adalah kemampuan mengenali, mengelola emosi diri sendiri sehingga tercipta keharmonisan hubungan dengan orang lain. Indikator kecerdasan emosi adalah emosi sendiri, mengelola emosi, memotivasi, empati terhadap orang lain, dan membina hubungan dengan orang lain.

Terkait dengan hal tersebut, penelitian ini bertujuan untuk mengembangkan instrumen bakat keguruan yang valid dan reliabel.

\section{Metode Penelitian}

Pengembangan instrumen ini mengacu pada metode yang dikembangkan oleh Gable (1986, pp. 170-177), terdiri atas lima belas tahapan yang dapat dikelompokkan tiga bagian yaitu pra-pengembangan, pengembangan konsep, dan uji coba. Tahap pra pengembangan dilakukan kajian pustaka, sehingga diperoleh kerangka konsep bakat keguruan. Tahap pengembangan konsep bakat keguruan dikaji melalui focus group discussion dan validasi ahli yang yang terdiri atas ahli pengukuran, pendidikan, bahasa, dan psikologi. Tahap uji coba dilakukan untuk menguji keseuaian konsep bakat keguruan dengan data lapangan. Uji terbatas dilakukan pada 3 mahasiswa Universitas Negeri Yogyakarta untuk mengetahui keterbacaan instrumen, waktu yang dibutuhkan untuk menjawab pertanyaan dan pernyataan isntrumen, sedangkan uji coba lapangan dilakukan di FKIP Universitas Bengkulu dengan jumlah responden 630 mewakili seluruh program studi yang ada.

Kreativitas pedagogi diukur dengan Tes Kreativitas Verbal (TKV) seperti yang dilakukan oleh Munandar (1999, p.81). Butir-butir pertanyaan kreativitas pedagogi disusun model what if not yaitu metode untuk mengungkap kemampuan siswa dalam pemecahan masalah jika disajikan satu alternatif pemecahan masalah (Shriki, 2013; Silver, 1997). Komitmen pedagogi dan kecerdasan emosi diukur dengan inventori model Guttman (Nunnally, 1978, pp.45-46; Rankin, Knezek, Wallace \& Zhang, 2004, p.99) dengan tiga pilihan berjenjang dengan penskoran 1 sampai dengan 3, dengan penempatan urutan skor secara acak, agar tidak mudah ditebak skornya.

Analisis validitas isi menggunakan rumus scale content validity index (S-CVI) dari Linn (1990) dan Polit \& Beck (2006). Kualitas butir instrumen setiap dimensi bakat keguruan dianalisis dengan pendekatan item response theory partial credit model atau IRT PCM (Adams \& Khoo, 1996, p.26; Andrich, 1978). Untuk menguji konstruk bakat keguruan dilakukan dengan confirmatory factor analysis (CFA) dari Kirsch \& 
Guthrie (1980) dan Shavelon \& Stanton (1975). Model konstruk fit jika memenuhi minimal 3 kriteria, seperti yang dikemukakan oleh Joreskorg \& Sorbom (2003) dan Schermelleh-Engel, Moosbrugger \& Mueler (2003). Reliabilitas instrumen bakat keguruan diperoleh dengan menggunakan reliabilitas gabungan (Mardapi, 2012, p.93; Nunnally, 1978, p. 248). Bukti validitas instrumen diperkuat dengan pendekatan validitas eksternal yaitu validitas konkuren dan konvergen. Kriteria eksternal instrumen kreativitas pedagogi menggunakan tes kecerdasan umum (IQ), instrumen komitmen pedagogi, kecerdasan emosi menggunakan instrumen Edward Preference Persona-litySchedule (EPPS). Validitas konvergen diperoleh dengan pendekatan multitrait multimethod matrix (Campbell \& Fiske, 1959) dengan kriteria eksternal pengamatan (observasi) komitmen pedagogi dan kecerdasan emsosi.

\section{Hasil Penelitian dan Pembahasan}

Hasil pengembangan instrumen diperoleh konstruk bakat keguruan yang terdiri atas tiga dimensi, yaitu kreativitas pedagogi, komitmen pedagogi, dan kecerdasan emosi. Konstruk bakat keguruan mempunyai validitas isi sebesar 0,93. Kreativitas pedagogi terdiri atas 4 faktor yaitu kecepatan berpikir, keluwesan berpikir, keaslian berpikir, dan elaborasi beripikir. Masing-masing faktor terdiri atas 8 butir pertanyaan uraian terbatas, sehingga jumlah seluruhnya 32 butir pertanyaan. Dimensi kreativitas pedagogi mempunyai validitas isi sebesar 0,92 . Komitmen pedagogi terdiri atas motivasi terhadap tugas, penyelesaian tugas, tanggung jawab terhadap tugas, dan keuletan menjalankan tugas. Setiap faktor terdiri atas $8 \mathrm{bu}-$ tir pernyataan yang diikuti 3 pilihan jawaban bertingkat. Dimensi komitmen pedagogi mempunyai validitas isi sebesar 0,94 . Kecerdasan emosi terdiri atas 5 faktor yaitu mengenali emosi diri sendiri, mengelola emosi, motivasi diri, empati, dan hubngan sosial. Setiap faktor terdiri atas 8 butir pertanyaan, sehingga jumlah seluruhnya 40 butir. Kecerdasan emosi mempunyai validitas isi sebesar 0,97 .
Uji coba lapangan untuk membuktikan kesesuaian antara konsep dan data empirik. Hasil analisis butir dengan pendekatan IRT PCM. Hasil analisis menunjukkan bahwa nilai infit instrumen kreativitas pedagogi bergerak dari 0,88 sampai dengan 1,23, masih dalam rentang batas infit mean square (MNSQ) untuk butir yaitu 0,77 sampai dengan 1,3. Infit mean square diperoleh mean 1,01 , standar deviasi 0,07 . Outfit mean square diperoleh mean 1,01 dan standar deviasi 0,06 . Infit t dengan rata-rata 0,09 dan standar deviasi 1,05. Hasil estimasi testi infit mean square diperoleh 1,02 dengan standar deviasi 0,04 . Infit $t$ dengan rata-rata $-0,04$ dan standar deviasi 1,0. Outfit mean square 0,08 dan standar deviasi 1,06. Koefisien reliabilitas sebesar 0,94 . Nilai informasi kemampuan kreativitas pedagogi antara $-2,05$ sampai dengan $+1,4$.

Nilai infit komitmen pedagogi bergerak dari nilai infit terkecil 0,77 dan terbesar 1,18 masih di dalam interval syarat infit mulai dari 0,77 sampai dengan 1,3. Bahwa estimasi butir infit mean square diperoleh mean 0,99 dan SD sebesar 0,08, sedangkan outfit mean square diperoleh mean 0,98 dan SD sebesar 0,07. Infit $t$ dengan mean sebesar 0,15 dan SD sebesar 1,05, sedangkan outfit $t$ dengan mean sebesar 0,08 dan SD sebesar 0,1,7. Koefisien reliabilitas instrumen komitmen pedagogi sebesar 0,707. Nilai informasi kemampuan (ability) komitmen pedagogi sampai,+ 01 .

Kecerdasan emosi mempunyai nilai infit terkecil 0,86 dan terbesar 1,28 masih di dalam interval syarat infit 0,77 sampai dengan 1,3, sedangkan estimasi butir infit mean square diperoleh rata-rata sebesar 0,99 dan standard deviation sebesar 0,08 , sedangkan outfit mean square diperoleh mean 0,97 dan SD sebesar 0,16. Infit $t$ dengan mean sebesar 0,19 dan SD sebesar 1,01, sedangkan outfit t dengan mean sebesar $-0,08$ dan SD sebesar 1,06. Hasil estimasi testi menunjukkan infit means square 1,00 dan standar deviasi 0,04, outfit means square 0,97 dan standar deviasi 0,03 . Kecerdasan emosi mempunyai nilai informasi responden dengan kemampuan (ability) sampai +0,4. Ketiga dimensi bakat 
keguruan menurut Adams \& Koo (1996, p. 91) semua instrument dimensi bakat keguruan baik butir maupun testi model cocok dengan IRT PCM.

Tabel 1. Hasil analisis CFA

\begin{tabular}{llllc}
\hline No & $\begin{array}{c}\text { Kriteria } \\
\text { GOF }\end{array}$ & $\begin{array}{c}\text { Cut off } \\
\text { value }\end{array}$ & $\begin{array}{c}\text { Hasil } \\
\text { penelitian }\end{array}$ & kecocokan \\
\hline 1. & df & - & 56 & - \\
2. & Chi-Square & $\leq 112$ & 67,88 & baik \\
3. & p-value & $\leq 0,05$ & 0,13274 & baik \\
4. & RMSEA & $\leq 0.08$ & 0,018 & baik \\
5. & RMR & $\leq 0,05$ & 0,0048 & baik \\
6. & NFI & $\geq 0,90$ & 0,98 & baik \\
7. & NNFI & $\geq 0,90$ & 1,00 & baik \\
8. & IFI & $\geq 0,90$ & 1,00 & baik \\
9. & GFI & $\geq 0,90$ & 0,98 & baik \\
10. & AGFI & $\geq 0,90$ & 0,97 & baik \\
\hline
\end{tabular}

Hasil pengujian second order CFA konstruk bakat keguruan diperoleh 13 variabel manifes yang memiliki nilai t hitung lebih besar dari 1,96 dan nilai koefisien faktor lebih besar dari 0,5, namun ada empat variabel manifes dengan muatan faktornya kurang dari 0,5. Variabel tersebut adalah mengenali emosi diri sendiri dengan muatan faktor 0,44 , mengelola emosi diri sendiri dengan muatan faktor 0,49 dan nilai t sebesar 8,00 , empati terhadap orang lain dengan muatan faktor 0,42 dan nilai t sebesar 6,50 , serta hubungan sosial dengan muatan faktor 0,30 dan nilai t sebesar 5,31.

Analisis model CFA menghasilkan Chi-square sebesar 67,88, df sebesar 56, p sebesar 0,13274, dan RMSEA sebesar 0,018. Hasil pengujian konstruk bakat keguruan memenuhi syarat goodness of fit statistics (GOF). Hubungan antar variabel manifes dengan variabel laten instrumen bakat keguruan disajikan dalam Gambar 1.

Muatan faktor variabel laten kreativitas pedagogi sebesar 0,29 dengan nilai $t$ sebesar 3,06 dengan $\mathrm{p}<0,05$. Muatan faktor komitmen pedagogi sebesar 0,86 dengan nilai t sebesar 3,27 dengan $p<0,05$. Muatan faktor kecerdasan emosi sebesar 0,27 dengan nilai t sebesar 2,72 dengan $\mathrm{p}<0,05$. Konstruk penyusun bakat keguruan hanya komitmen pedagogi dengan muatan faktor lebih besar 0,30, namun kecerdasan emosi dan kreativitas pedagogi kedudukan sebagai penyusun konstruk bakat keguruan signifikan karena $\mathrm{P}<0,05$. Dengan demikian, konstruk bakat keguruan terdiri atas kerativitas pedagogi, komitmen pedagogi, dan kecerdasan emosi didukung oleh data empririk. Dari ketiga dimensi bakat keguruan ternyata komitmen pedagogi mempunyai muatan faktor paling besar, berikutnya dimensi kecerdasan emosi, dan terakhir kreativitas pedagogi. Hasil analisis ini ternyata bakat keguruan didominasi oleh dimensi non-kognitif.

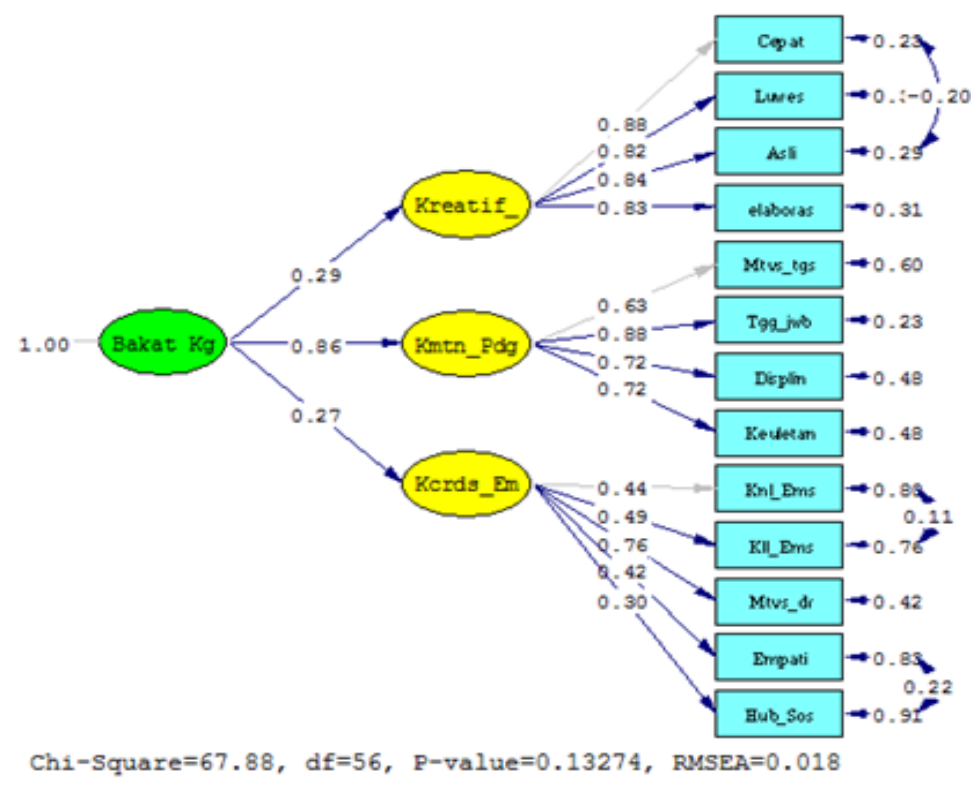

Gambar 1. Hasil Uji CFA Konstruk Bakat Keguruan 


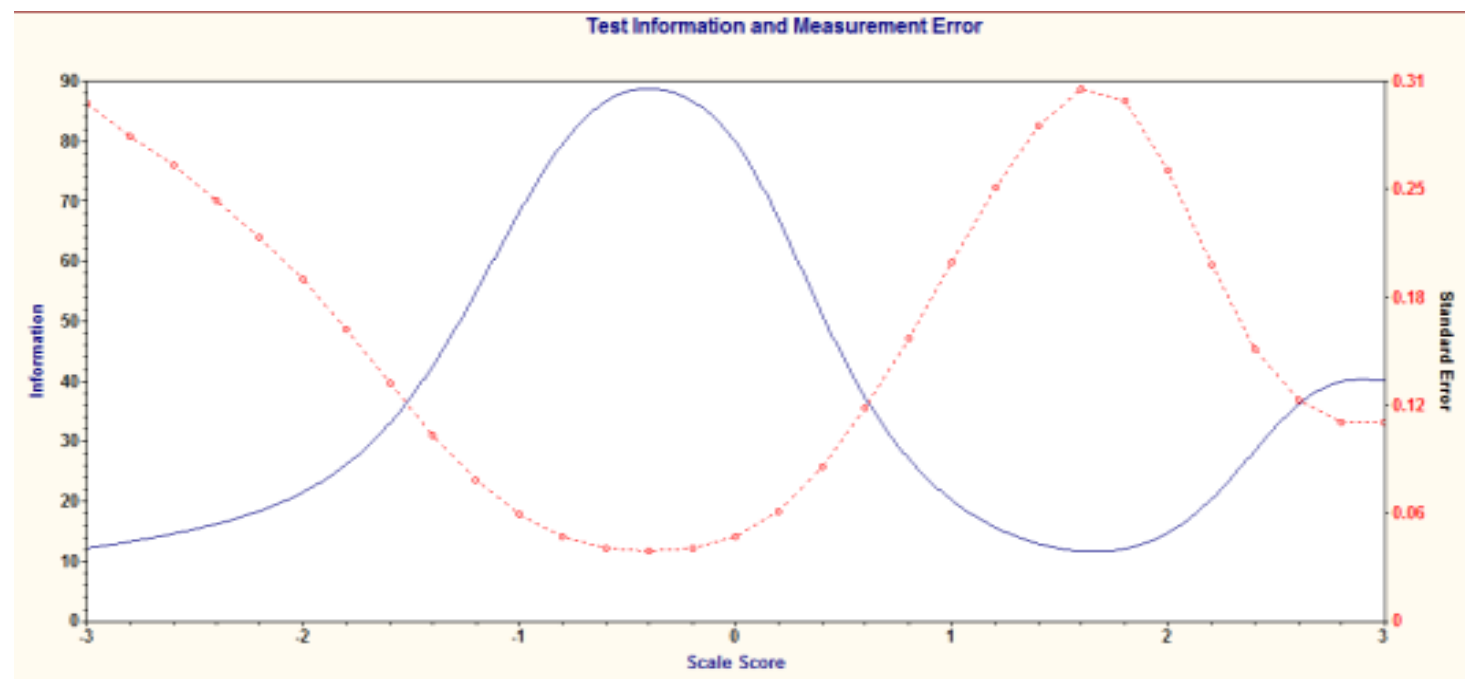

Gambar 2. Nilai Total Informasi

Berdasarkan Gambar 2, nilai fungsi informasi bakat keguruan antara -2,5 sampai dengan $+0,7$, dan di atas 2,58. Hal ini berarti instrumen bakat keguruan sesuai digunakan pada individu dengan kemampuan (ability) antara -2,5 sampai $+0,7$ dan di atas 2,58. Nilai informasi antara $-2,5$ sampai $+0,7$ sekitar 0,88 . Nilai informasi antara $+0,7$ sampai dengan $+2,5$ terjadi penurunan informasi, hal ini berarti individu yang mempunyai kemampuan pada interval ini tidak tepat mengerjakan soal-soal instrumen ini. Fungsi informasi di atas 2,5 berkisar 0,09 .

Tabel 2. Validitas Konkuren

\begin{tabular}{llcc}
\hline No Variabel & SPM & EPPS \\
\hline 1. & Kreativitas pedagogi & 0,163 & - \\
& $\mathrm{p}$ & 0,379 & \\
2. & Komitmen pedagogi & - & 0,355 \\
& $\mathrm{p}$ & & $0,050^{*}$ \\
3. & Kecerdasan emosi & - & 0,459 \\
& $\mathrm{p}$ & & $0,009^{*}$ \\
\hline
\end{tabular}

Tabel 2 menunjukkan bahwa uji validitas konkuren antara kreativitas pedagogi dengan tes SPM sebesar 0,163. Hubungan antara skor kreativitas pedagogi dengan skor ini tidak signifikan, hal ini ditunjukkan besarnya p yang muncul 0,379 . Korelasi sebesar 0,163 ini menunjukkan bahwa antara kreativitas dan pedagogi merupakan konsep yang berbeda. Korelasi antara kreativitas pedagogi dengan kecerdasan (IQ) sebesar 0,163 membuktikan bahwa korelasi ini sangat kecil, dibanding dengan kriteria validitas eksternal yang mensyaratkan minimal 0,350 . Instrumen bakat keguruan yang terdiri dari kreativitas pedagogi, komitmen pedagogi, dan kecerdasan emosi.

Berdasarkan Tabel 3 korelasi antara hasil tes kreativitas dengan kecerdasan umum IQ sebesar 0,163.

Tabel 3. Rangkuman Multitrait Multimethod

\begin{tabular}{lccc}
\hline Dimensi & IQ & Obs KP Obs KE \\
\hline Kreativitas Pedagogi & 0,163 & - & - \\
Komitmen Pedagogi (KP) & & 0,832 & - \\
Kecerdasan Emosi (KE) & & & 0,806 \\
\hline
\end{tabular}

Banyak penelitian tentang hubungan antara inteligensi dan kreativitas yang menunjukkan bahwa kreativitas belum tentu merupakan fungsi dari inteligensi (Renzulli, 1978). Kim (2005) melakukan meta penelitian hubungan antara kreativitas dan kecerdasan. Sampel 447 koefisien korelasi dari 21 studi dengan sampel 45.880 orang. Koefisien korelasi rata-rata yang kecil $r=0,174$. Terdapat korelasi yang rendah antara kreativitas dengan kecerdasan (Silvia, 2008). Korelasi antara kreativitas pedagogi dengan kecerdasan yang rendah ini sesuai dengan penelitian yang dilakukan oleh Naderi \& Abullah (2010) bahwa kreativitas menjelas- 
kan error variance kecerdasan sebesar 0,135. Hal ini berarti hubungan antara kreativitas dan kecerdasan sangat rendah. Hasil penelitian yang dilakukan oleh Cho et al. (2010) menunjukkan bahwa antara proses operasi berpikir kreatif berbeda dengan proses berpikir cerdas. Fuchs-Beauchamp, Karnes, \& Johnson (1993) menyebutkan bahwa ada korelasi antara kecerdaasan dan kreativitas. Anak-anak dengan IQ kurang dari 120 korelasinya moderat, sedangkan anak-anak dengan IQ di atas 120 korelasi dengan kreativitas menurun drastis sebesar 0,12. Jauk et al. (2013 menemukan bahwa kreativitas sangat dipengaruhi oleh personalitas, tidak ditemukan bahwa kreativitas yang tinggi ditentukan oleh kecerdasan yang tinggi. Penelitian pada masyarakat Korea yang dilakukan oleh Kim (2009) menyebutkan bahwa kreativitas dipengaruhi oleh budaya. Korelasi yang rendah ini menunjukkan bahwa secara empirik kreativitas pedagogi berbeda dengan konsep kecerdasan (IQ). Dari berbagai penelitian dan pendapat tersebut, ternyata konsep kreativitas berbeda dengan konsep kecerdasan IQ. Hal ini menunjukkan bahwa kreativitas dan kecerdasan menunjukkan konsep yang berbeda, temuan ini mendukung konsep keberbakatan the three ring concept dari Renzulli.

Korelasi hasil pengukuran komitmen pedagogi dengan inventori dan hasil observasi komitmen pedagogi sebesar 0,832, hal ini menunjukkan bahwa antara pengukuran inventori dan observasi sesuai convergent. Korelasi sebesar 0,832 tersebut menunjukkan bahwa instrumen dimensi komitmen pedagogi mempunyai validitas konvergen. Korelasi hasil pengukuran kecerdasan emosi dengan inventori dengan hasil observasi sebesar 0,806, hal ini menunjukkan bahwa kedua pengukuran tersebut mengukur satu konsep yang sama convergent. Dengan demikian, kecerdasan emosi memiliki validitas konvergen.

Penelitian yang dilakukan oleh Kadyschuk (1997) menyebutkan bahwa komitmen guru terdiri atas pengalaman kerja, karakteristik kerja, dan kepemimpinan. Hal ini berbeda dengan komitmen pedagogi yang dikembangkan dalam penelitian ini. Perbedaannya terletak pada cakupan masalah yang diteliti, yaitu motivasi terhadap tugas yang diembannya, tanggung jawab terhadap tugas, disiplin terhadap tugas, dan keuletan/ketangguhan dalam menjalankan tugas yang berkaitan dengan tugas guru sebagai pendidik. Perbedaan lainnya adalah bentuk pernyataannya. Kadyshuck mengembangkan instrumen dalam bentuk model Likert, sedangkan dalam penelitian ini bentuk butir-butirya berupa pernyataan yang diikuti dengan pilihan bergradasi seperti yang dikembangkan oleh Guttman (Rankin, Knezek, Wallace \& Zhang, 2004).

Penelitian yang dilakukan oleh Justice \& Espinoza (2007) menyebutkan bahwa kecerdasan emosi berkaitan dengan keterampilan calon guru dalam hal kenyamanan, empati, pengambilan keputusan, mendorong kekuatan, manajemen waktu, komitmen etika, harga diri, manajemen stress, dan mengubah orientasi. Ada hal yang berbeda dengan penelitian ini yaitu komitmen etika masuk dalam komitmen pedagogi, dan keterampilan hubungan sosial yang ada dalam penelitian ini. Di samping itu, butir-butir yang dikembangkan dalam penelitian ini berbentuk pernyataan yang diikuti dengan pilihan bergradasi.

Penelitian yang dilakukan oleh Corcorana \& Tormey (2013) tentang hubungan antara kecerdasan emosi dengan kinerja praktikum mengajar. Tidak semua faktor kecerdasan emosi yang berhubungan signifikan dengan praktik mengajar, namun faktor perception appraisal and expression of emotion (PEIQ) mempunyai hubungan yang signifikan dengan kinerja praktik mengajar. Hal ini sesuai dengan hasil penelitian ini bahwa kecerdasan emosi merupakan dimensi dari bakat keguruan.

Berdasarkan uraian tersebut, ada perbedaan pada antara komitmen pedagogi dengan komitmen guru yang dikembangkan oleh Kadyschuk (1997), dan antara kecerdasan emosi dengan kecerdasan emosi yang dikembangkan oleh Justice \& Espinoza (2007). Kreativitas pedagogi yang dikembangkan dalam penelitian ini belum di- 
kembangkan oleh peneliti lain. Dengan demikian ada kebaruan dalam penelitian ini.

Hasil pengukuran bakat keguruan (BKg) mahasiswa FKIP Universitas Bengkulu tahun akademik 2014/2015 disajikan pada Tabel 4.

Tabel 4. Distribusi Frekuensi BKg

\begin{tabular}{ccc}
\hline No & Interval & $\mathrm{f}$ \\
\hline 1. & $170-181$ & 5 \\
2. & $182-193$ & 13 \\
3. & $194-205$ & 51 \\
4. & $206-217$ & 91 \\
5. & $218-229$ & 126 \\
6. & $230-241$ & 123 \\
7. & $242-253$ & 96 \\
8. & $254-265$ & 76 \\
9. & $266-277$ & 37 \\
10. & $278-289$ & 12 \\
& Jumlah & 630 \\
\hline
\end{tabular}

Berdasarkan Tabel 4, dapat diketahui bahwa skor 104 sampai 184 atau nilai 1 sampai dengan 3,9 (kurang sekali berbakat) terdapat 8 mahasiswa atau 1,27\%. Skor 185 sampai dengan 228 atau nilai 4 sampai dengan 5,9 (kurang berbakat) terdapat 261 mahasiswa atau 41,58\%. Skor 229 sampai 269 atau nilai 6 sampai dengan 7,9 (cukup berbakat) sebanyak 262 mahasiswa atau $41,58 \%$. Skor $270-312$ atau nilai 8 sampai dengan 10 (berbakat) sebanyak 36 mahasiswa atau $5,72 \%$.

\section{Simpulan dan Saran}

Berdasarkan hasil analisis dan pembahasan, pengembangan instrumen bakat keguruan dapat disimpulkan berikut ini. Instrumen bakat keguruan yang dikembangkan tergolong baik, karena mempunyai indeks validitas isi yang lebih besar daripada batas minimal yang ditentukan, didukung de-ngan data yang memenuhi syarat goodness of fit statistics, dan mempunyai koefisien reliabilitas yang tinggi.

Instrumen kreativitas pedagogi, komitmen pedagogi, dan kecerdasan emosi merupakan dimensi bagian instrumen bakat keguruan tergolong baik, karena mempunyai indeks validitas isi dan koefisien reliabilitas yang tinggi.

Instrumen kreativitas pedagogi mempunyai validitas konkuren dengan standard progesive matrices (SPM) yang rendah, sedangkan dimensi komitmen pedagogi dan kecerdasan emosi mempunyai indeks validitas konkuren dengan EPPS yang cukup. Instrumen komitmen pedagogi dan instrumen kecerdasan emosi mempunyai validitas konvergen yang tinggi.

Kondisi bakat keguruan mahasiswa FKIP Universitas Bengkulu mempunyai distribusi frekuensi normal, jumlah mahasiswa yang mempunyai bakat keguruan kategori rendah dan katagori tinggi jumlahnya sedikit, sedangkan jumlah mahasiswa berbakat katagori sedang jumlahnya paling banyak.

Penelitian belum mencakup batas skor potensi bakat keguruan, oleh karena itu perlu dilakukan penelitian lanjutan tentang cut score bakat keguruan.

\section{Daftar Pustaka}

Açikgöz, F. (2005). A studi on teacher characteristics and their effects on students attitudes. The Reading Matrix, 5(5), 103-115.

Adams, R. J., \& Khoo Siek Toon. (1996). QUEST. The Interactive Test Analysis System. Camberwell, Victoria: The Australian Council for Educational Research.

Alkharusi, H., Kazem, A. M., \& Musawai, A. A. (2011). Knowledge, skills, and attitudes of preservice and in-service teachers in educational measurement. Asia-Pacific Journal of Teacher Educational 39(2), 113-123.

Andrich, D. (1978). A rating formulation for ordered response categories. Psichometrika, 43(4), 561-573.

Anonim. (1977). Piagam dan Peraturan besar Persatuan Taman Siswa. Yogyakarta: Majelis Luhur Persatuan Taman Siswa. 
Beetlestones, F. (2011). Creative Learning. Bandung: Nusa Media.

Bingham, W. V. (1948). What is an aptitude? Test Bulletin Servive, 36, 1-3.

Block, A. A. (2008). Why should I be a teacher? Journal of Teacher Education, 59, 416-427.

Bramwell, G., Reilly, R., Lilly, F. R., Kronish, N., \& Chennabathni, R. (2011). Creative teachers. ProQuest, 33(4), 228-237.

Campbell, D. T., \& Fiske, D. W. (1959). Convergent and discriminant validation by the multitraitmultimethod matrix. Psychological Bulletin, 56(2), 81-105.

Cho, S. H., te Nijenhuis, J, van Vianen, A. E. M., Kim, H. B., \& Lee, K. H. (2010). The relationship between diverse components of intelligence and creativity. Journal Creative Behavior, 44(2), 125-137.

Choi, P. L., \& Tang, S. Y. F. (2009). Teacher commitment trends: Cases of Hong Kong teachers from 1997 to 2007. Teaching and Teacher Education 25, $767-$ 777.

Corcorana, R. P., \& Tormey, R. (2013). Does emotional intelligence predict student teachers' perfor-mance? Teaching and Teacher Education, 35, 3442

Dawson, S., Tan, J. P. L., \& McWilliam, E. (2011). Measuring crea-tive potential: Using social network analysis to monitor a learners' creative capacity. Australasian Journal of Edu-cational Technology, 27(6), 924-942.

Dicky, N. (2011). Indonesian primary teachers' mathematical knowledge for teaching geometry: implications for educational policy and teacher preparation programs. Asia-Pacific Journal of Teacher Educational, 39(2), 151-164.
Dorman, J. (2008). Testing a model for teacher burnout. Australian Journal of Educational \& Developmental Psychology, 3, 35-47.

Fuchs-Beauchamp, K. D., Karnes, M. B., \& Johnson, L. J. (1993). Creativity and Intelligence in Preschoolers. Gifted Child Quarterly, 37(3), 113-117.

Gable, R. K. (1986). Instrument develompment in affective domain. Boston: KluwerNijhoff Publishing.

Garcia, P., Kupczynski, L., \& Holland, G. (2011). Impact of teacher personality styles on academic excellence of secondary students. National Forum of Teacher Educational Journal, 21(2).

Gardner, H. (2006). Multiple Intelligences. New York: Basic Book.

Gu, Q., \& Day, C. (2013). Challenges to teacher resilience: conditions count. British Educational Research Journal, 39(1), 22-44.

Iordanoglou, D. (2007). The relationship between emotional intelligence and leadership effectiveness, commitment, and satisfaction. Journal of Leadership Studies, 1(3), 57-66.

Ishak, N. M., Piet, I. I. \& Ramli, R. (2010). Emotional intelligence of Malaysian teacher : A comparative study on teacher in daily and residential school. Procedia-Soscial and Behavior Sciences, 9, 604-612.

Jacobs, K., \& Mitchell, J. (2008). Emotional intelligence: hidden ingredient for emotional health of teachers. Africa Education Review 5(11), 131-143.

Jauk, E., Benedek, M., Dunst, B., \& Neubauer, A. C. (2013). The relationship between intelligence and creativity: New support for the threshold hypothesis by means of empirical breakpoint detection. Intelligence, 41, 212-221. 
Joreskorg, K., \& Sorbom, D. (2003). Lisrel 8: User's reference guide. Chicago: Scientific software international.

Justice, M., \& Espinoza, S. (2007). Emotional intelligence and beginning teacher candidates. Education; ProQuest, 127(4), 456-461.

Kadyschuk, R. (1997). Teacher commitment: a study of organizational commitment, profesional commitment, and union commitment of teachers in public school in Saskatchewan. University of Saskatchewan, Canada. Diunduh pada tanggal 21 mei 2012 dari

http://ecommons.usask.ca/handle/1 $\underline{0388 / \text { etd-10212004-000011 }}$

Kim, K. H. (2005). Can Only Intelligent People Be Creative? The Journal of Secondary Gifted Education XVI (2/3), 57-66.

Kim, K. H. (2009). The relationship between Asian culture and creativity. Journal of Creative Behavior, 43 ( 2 ), 73 93.

Kirsch, I. S., \& Guthrie, J. T. (1980). Construct validity of functional reading tests. Journal of educational measurement, 1(7), 281-293.

Kokkinos, C. M., Charalambous, K., \& Davazoglou, A. (2010). Primary school teacher interpersonal behavior through the lens of students' Eysenckian personality traits. Soc Psychol Educ., 13, 63-349

Kraft, M. A., \& Dougherty, S.M. (2013). The effect of teacher-family communication on student engagement: Evidence from a randomized field experiment. Journal of Research on Educational Effectiveness, 6, 199-222.

Kwok-wai, C. (2006). In-service teachers' motives and commitment in teaching. Hong Kong Teachers' Centre Journal, 5, 112-128.
Leff, S. S., Kupersmidt, J. B., Patterson, C. J., \& Power, T. J. (1999). Factors influencing teacher identification of peer bullies and victims. School Psychology Review, 28(3), 505-517.

Lilly, F. R., \& Bramwell-Rejskind, G. (2004). The dinamics of creativity teaching. Journal of Creative Behavior, 38, 102-124.

Linn, R. L. (1990). Measurement and evaluation in teaching. New York: McMilan Publishing Company.

Mardapi, D. (2012). Pengukuran penilaian dan evaluasi pendidikan. Yogyakarta: Nuha Litera.

Mardiana. (2006). Komitmen guru dalam melaksanakan tugas mengajar di SD Kecamatan Padang Panjang Timur. Jurnal guru, 2(59-77.).

Martinson, R. A. (1974). The Indentification of The Gifted and Tallent. California: Office of The Ventura County Superintended of Schools.

Mayer, J. D., Caruso, D. R., \& Salovey, P. (2000). Emotional intelligence meets traditional standards for an intelligence. Intelligence, 27(4), 267-298.

Munandar, S. C. U. (1999). Kreativitas dan keberbakatan: Strategi mewnjudkan potensi kereatif dan bakat. Jakarta: Gramedia Pustaka Utama.

Nunnally, J. C. (1978). Psychometric Theory. New York: McGraw-Hill Book Company.

Olson, C. O., \& Wyett, J. L. (2000). Teachers need affective competencies. Education, 120(4), 471-625.

Patton, P. (1977). Emotional Intelligence. Singapore: SNP Publishing Pte Ltd.

Polit, D. F., \& Beck, C. T. (2006). The content validity index: Are you sure you know what's being reported? Critique and recommendations. Research in Nursing \& Health, 29, 489-497.

Rankin, P. D., Knezek, G. A., Wallace, S., \& Zhang, S. (2004). Scaling method. New 
Jersey: Lawrence Erlbaum Associates Publisher.

Razak, N. A., I., Darmawan, I. G. N, Keeves, J. P. (2010). The influence of culture on teacher commitment. Soc Psychol Educ., 13, 185-205.

Renzulli, J. S. (1978). What makes giftedness?: Reexamining a Definition. Phi Delta Kappan, 60(3), 180-184.

Renzulli, J. S. (1986). The three-ring conception of giftedness: $A$ developmental model for creative productivity. New York: Cambridge University Press.

Renzulli, J. S. (1998). The three-ring conception of giftedness. In S. M. Baum, Reis, S. M., \& Maxfield, L. R. (Ed.), Nurturing the gifts and talents of primary grade students. Mansfield Center, CT: Creative Learning Press.

Roth, G., Kanat-Maymon, Y., \& Bibi., U (2010). Prevention of school bullying: The important role of autonomy-supportive teaching and internalization of pro-social values. British Journal of Educational Psychology 81(4), 656-666.

Rowe, K. J. (2003). The Importance of Teacher Quality as a Key Determinant of Students' Experiences and Outcomes of Schooling. Paper presented at the ACER Improving Learning, Melbourne.

Salkind, N. J. (2008). Aptitude Encyclopedia of educational psychology. New York: Sage Publisher.

Sawyer, R. K. (2004). Creative teaching: collaborative discussion as disciplined improvisation. Educational Researcher, 33(2), 12-20.

Schermelleh-Engel, K., Moosbrugger, H., \& Mueler, H. (2003). Evaluating the fit of structural equation models: Tests of significance and descriptive goodness-of-fit measures. Methods of Psychological Research 8(2), 23-74.

Shavelon, R. J., \& Stanton, G. C. (1975). Construct validation : methodology and application to three neasures of cognitive struktur. Journal Educational Measurement, 12(2), 67- 85.

Shriki, A. (2013). A model for assessing the development of students' creativity in the context of problem posing. Creative Education, 4(7), 430-439.

Sigmar, L., Hynes, G., \& Cooper, T. (2010). Emotional intelligence: Pedagogical considerations for skills-based learning in business communication courses. Journal of Instructional Pedagogies, 3(June), 1-13.

Silver, E. A. (1997). Fostering creativity through Instruction rich in Mathematical problem solving and problem posing. ZDM- The International Journal on Mathematics Education, 29, 75-80.

Silvia, P. J. (2008). Another look at creativity and intelligence: Exploring higher-order models and probable confounds. Personality and Individual Differences, 44, 1012-1021.

Sternberg, R. J., \& Davidson, J. E. (2005). Conceptions of Giftedness. Cambridge: Cambridge University Press.

Stiggins, R. J. (1992). High quality classroom assessment: What does it really mean? Educational Measurement: Issues and Practice, 11(2), 35-39.

Strean, W. B. (2011). Creating student engagement? HMM: Teaching and learning with humor, music, and movement. Creative Education, 2(3), 189-192.

Sudarnoto, L. F. N. (2009). Memberdayakan profesi pendidik untuk mencapai peningkatan kualitas kehidupan kerja. Universitas Atma Jaya. Yogyakarta.

Sudiyat, I. (1987). Pamong yang berwatak satriya pandbita dan pinandhita sanatriyo \& belajar menjadi siswa ki hadjar dewantara. Yogyakarta: Sarjanawiyata Tamansiswa.

Sugiharto. (2003). Kemampuan guru mengelola pembelajaran Fisika di SLTP

Pengembangan Instrumen Bakat Keguruan ... - 109

Wasidi, Djemari Mardapi 
$\mathrm{N}$ Kota Banjarmasin. Jurnal Penelitian dan Evaluasi, 5(6), 116-127.

Sundari, A. (2013). Emotional intelligence for professional excellence. International journal of the frontiers of english literature and the patterns of ELT 1(2), 1-13.

Teven, J. S. (2007). Teacher Caring and Classroom Behavior: Relationships with Student Affect and Perceptions of Teacher Competence and Trustworthiness. Communication Quarterly, 55(4), 433-450.

Twemlow, S. W., Fogany, P., Sacco, F. C. \& Brethour Jr, J.R. (2006). Teacher who bully students: A hidden trauma. International Journal of Social Psychiatry, 52(3), 187-198. 